\title{
Movements and Dive Behaviour of Belugas in Northern Quebec
}

\author{
MICHAEL C.S. KINGSLEY, ${ }^{1,2}$ SERGE GOSSELIN ${ }^{1,3}$ and GARY A. SLENO ${ }^{1,4}$
}

(Received 18 November 1999; accepted in revised form 16 November 2000)

\begin{abstract}
Three adult and three juvenile belugas were fitted with satellite-linked radio tags in eastern Hudson Bay in midAugust 1993, and one adult was tagged in mid-October 1995 in extreme northeastern Hudson Bay. The tags transmitted data on dive behaviour, and the receiving satellite calculated positions by Doppler-shift triangulation. The belugas tagged in summer in eastern Hudson Bay made no directed or long-distance movements while the tags were attached. Their range did not include the Belcher Islands, and belugas observed in aerial surveys of those islands do not appear to belong to the eastern coastal stock. The single beluga tagged in northern Quebec in October moved into the deep water of western Hudson Strait and travelled east along the southern coast of Hudson Strait, slowing up on reaching shallower water off Salluit and near Charles Island. This whale was still off Salluit when the tag stopped transmitting.

All the tagged belugas dived intensively while the tags were attached, although there were individual differences, some belugas diving noticeably less than others. Dive behaviour varied over time, with periods lasting several days of concentrated diving interspersed with periods of less intense diving. 'Intense' periods entailed diving for up to $80 \%$ of the time. All belugas, even the one that was in deep water in Hudson Strait, showed dive depth characteristics that were consistent with diving usually to the bottom. However, all belugas always — even in deep water-made dives that usually lasted less than $10 \mathrm{~min}$ and very seldom lasted more than $12 \mathrm{~min}$. Belugas tagged as pairs of adults and young showed striking correlations of dive behaviour. The data obtained indicate that it would be appropriate to correct aerial surveys by adding $85 \%$ to aerial counts.
\end{abstract}

Key words: beluga, Delphinapterus leucas, dive behaviour, migration, movement, Hudson Bay, Hudson Strait, visibility, dive speed

RÉSUMÉ. Mi-août 1993, on a équipé trois bélougas adultes et trois bélougas juvéniles de radio-émetteurs en liaison avec un satellite dans l'est de la baie d'Hudson et mi-octobre 1995 on a équipé un adulte aux confins nord-est de la baie d'Hudson. Les émetteurs ont transmis des données sur le comportement en plongée, et le satellite récepteur a calculé les positions par triangulation de décalage Doppler. Les bélougas équipés en été dans l'est de la baie d'Hudson ne se sont pas déplacés vers un endroit particulier ou sur une longue distance pendant que les émetteurs étaient fixés. Leur territoire ne comprenait pas les îles Belcher, et les bélougas observés lors de survols aériens effectués sur ces îles ne semblent pas appartenir au stock côtier oriental. Le seul bélouga équipé en octobre dans le nord du Québec s'est rendu dans les eaux profondes du détroit d'Hudson occidental dont il a longé la côte méridionale vers l'est, ralentissant au niveau des eaux moins profondes au large de Salluit et près de l'île Charles. Cette baleine était toujours au large de Salluit quand l'émetteur a cessé de fonctionner. Tous les bélougas équipés ont plongé de façon intensive pendant que les émetteurs étaient fixés, bien qu'on ait noté des différences individuelles, certains bélougas plongeant visiblement moins que d'autres. Le comportement en plongée variait avec le temps, des périodes de plongée intense sur plusieurs jours étant séparées par des périodes de plongée moins intense. «Intense» signifie que les bélougas plongeaient jusqu'à 80 p. cent du temps. Tous les individus, même celui qui se trouvait dans l'eau profonde du détroit d'Hudson, montraient des caractéristiques de profondeur de plongée typiques de plongées atteignant généralement le fond. Toutefois, tous les bélougas - même en eau profonde - effectuaient toujours des plongées durant généralement moins de $10 \mathrm{mn}$ et dans de très rares cas plus de $12 \mathrm{mn}$. Les bélougas équipés en tant que paires adulte-jeune montraient des corrélations frappantes de comportement de plongée. Les données recueillies indiquent qu'il conviendrait de corriger les relevés aériens en ajoutant 85 p. cent aux dénombrements aériens.

Mots clés: bélouga, Delphinapterus leucas, comportement en plongée, migration, déplacement, baie d'Hudson, détroit d'Hudson, visibilité, vitesse de plongée

Traduit pour la revue Arctic par Nésida Loyer.

\footnotetext{
${ }^{1}$ Canadian Department of Fisheries and Oceans, Maurice Lamontagne Institute, 850 Route de la mer, Mont-Joli, Quebec G5H 2G9, Canada

${ }^{2}$ Present address: Greenland Institute of Natural Resources, P.O. Box 570, DK-3900 Nuuk, Greenland; mcsk@ natur.gl

${ }^{3}$ Canadian Department of Fisheries and Oceans, Fisheries Research Directorate, 200 Kent Street, Ottawa, Ontario K1A 0E6, Canada

${ }^{4}$ P.O. Box 54, Chute à Blondeau, Ontario K0B 1B0, Canada

(C) The Arctic Institute of North America
} 


\section{INTRODUCTION}

The beluga (Delphinapterus leucas) is a gregarious odontocete that migrates in summer to spend time in the shallow, brackish estuaries of Arctic rivers. Belugas are often heavily hunted at these concentration areas, which are associated with shallow calm waters, mild summer weather, and ready access to abundant whales.

Belugas summer in James Bay and on most of the coasts of Hudson Bay, and some stocks are very large (Smith and Hammill, 1986; Richard et al., 1990; Kingsley, 2000). Relationships between beluga stocks in Hudson Bay are complex and not fully known. The northern Quebec stocks may be genetically related to neighbouring stocks, and animals may sometimes transfer from one stock to another. The eastern Hudson Bay stocks have been depleted by hunting and are probably still well below their pristine levels (Reeves and Mitchell, 1987a, b; Kingsley, 2000). They are still exploited on the east coast of Hudson Bay at their estuarine summering areas (DFO, 1996; NAMMCO, 2000), and the exploitation of a renewable resource cannot be managed effectively without periodic estimates of numbers and trend. Aerial surveys permit estimates to be made of the numbers of belugas in large areas of eastern Hudson Bay (Smith and Hammill, 1986; Kingsley, 2000). However, the relationships between different groups of animals in aerial survey study areas are never clear, and it is impossible to judge whether all the belugas counted by aerial survey in eastern Hudson Bay belong to the stocks that are exploited at the coastal summering areas. Therefore, a further concern is how many of the belugas counted in aerial surveys belong to the exploited stock(s).

Belugas winter in the unconsolidated ice of Hudson Strait, in numbers estimated as similar to the total of the summering stocks in Hudson Bay (Finley et al., 1982). Belugas are not present near extreme northwestern Quebec in the height of summer (Gaston et al., 1985), but they pass the northwestern tip of Quebec in large numbers in spring and fall. They are then hunted on the northern east coast of Hudson Bay and the western south coast of Hudson Strait. In spring and fall, the estuarine summer concentration areas are unoccupied, so some beluga groups that are hunted at the height of summer farther south on the east coast of Hudson Bay may also be hunted in spring and fall in these more northerly areas. However, other stockssuch as the much larger western Hudson Bay stock, or the belugas that are seen in summer in James Bay-might also pass through these waters in fall and could contribute to these harvests.

Tagging has helped to clarify the movements and relationships of many species and stocks of fish and wildlife. It can give incontrovertible physical evidence of movement between areas or of mixing between groups that might otherwise be considered separate. However, recovery tagging is not very useful for belugas because implanted tags are not retained (Geraci and Smith, 1990), and flipper bands (Orr and Hiatt-Saif, 1992), which require live capture of individual belugas, are expensive to apply. Belugas have so far only been accessible for tagging purposes for a short period in the summer, which limits the questions that tagging can answer, and hunting - the main source from which tag returns are to be expected-is also strongly seasonal, which imposes similar constraints. The sustainable annual takes from monodontid populations are so low that very many tags would have to be applied, at large cost, to obtain a usable number of recoveries (Sergeant, 1973, 1981; Kingsley, 1989; Geraci and Smith, 1990). Natural tags, including nuclear and mitochondrial DNA and signatures of trace metals and other contaminants, are now being used to differentiate stocks (Brown Gladden et al., 1997; NAMMCO, 2000), but these methods have been mostly limited to hunted samples.

At best, effective conservation of the beluga stocks that summer on the eastern coast of Hudson Bay requires more information about stock structure, movements, and discreteness. At worst, the status of these stocks may be cause for serious concern. Conventional tagging methods are inapt to provide the needed information, as application is expensive, retention is uncertain, and recoveries are few. Remotely tracked radio tags, however, allow belugas to be followed without being recaptured, so movements and mixing can be studied outside the hunting season. Furthermore, the ease of capturing data on behaviour or physiology also allows inferences to be made about habitat use, so that ecosystems can be more precisely managed, or about how well different census methods can detect or count belugas, so that stock size estimates can be made more accurate. Radio tags tracked from satellites extend the range of this technique into remote areas, hostile seas, and inhospitable seasons. The present study represents initial attempts to apply this technique to the study of beluga movements and stock relationships in eastern Hudson Bay and the estimation of correction factors for aerial survey counts.

\section{METHODS}

\section{Study Area}

Hudson Bay is generally shallow. The eastern coastline of southern Hudson Bay has the shape of a circular arc (the 'Hudson Bay arc') extending from $54^{\circ} 40^{\prime} \mathrm{N}$ to $58^{\circ} 40^{\prime} \mathrm{N}$. The Belcher Islands, situated near the centre of the Hudson Bay arc, are associated with a wide plateau that extends to the east and reveals itself as numerous reefs and islets, between which the water is generally less than $40 \mathrm{~m}$ deep. From the eastern limit of this plateau, eastward and northeastward toward the mainland coast, the water is deeper, although seldom over $60 \mathrm{~m}$ deep. There are deeper trenches along the mainland coast, associated with chains of near-shore islands (Fig. 1). A trough over $100 \mathrm{~m}$ deep extends southwestward from near the mouth of Richmond Gulf, leading to the south of the Belcher Islands. Farther north along the coast of eastern Hudson Bay, the bottom slopes more steeply, and depths of $100 \mathrm{~m}$ are 


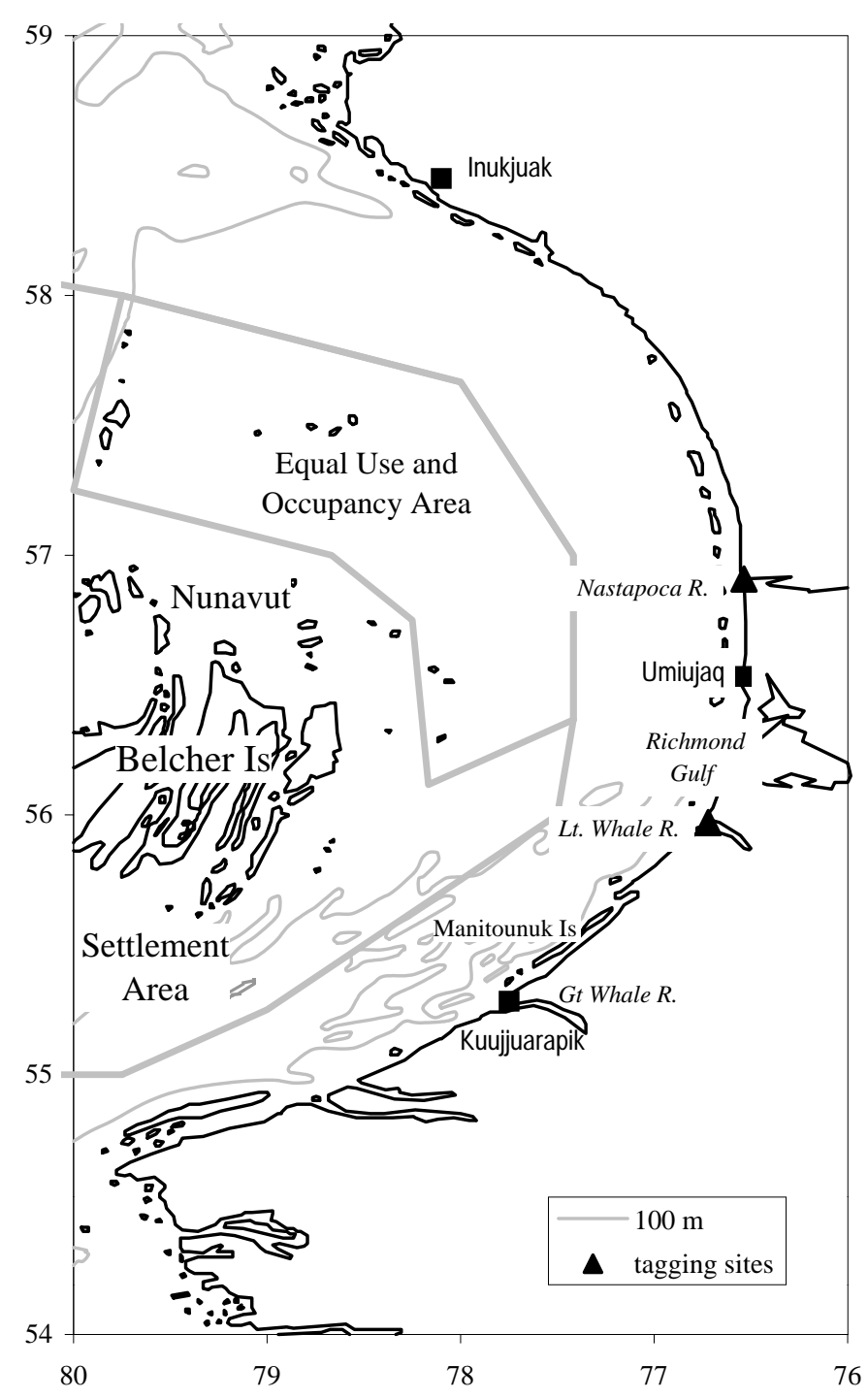

FIG. 1. Study area in eastern Hudson Bay, Nunavut, Canada, showing tagging sites and the $100 \mathrm{~m}$ isobath. Also shown are the Nunavut Settlement Area and Equal Use and Occupancy Area defined in the Nunavut Final Agreement.

reached within $20 \mathrm{~km}$ of the coast near Hudson Strait. The Hudson Strait shoreline at the northwestern tip of Quebec is precipitous, dropping to depths of $400 \mathrm{~m}$ within $5 \mathrm{~km}$ of the shore (Fig. 2).

In eastern Hudson Bay, belugas no longer frequent the estuary of the Great Whale River, once the site of large commercial beluga catches, but they still frequent the estuaries of the Little Whale and Nastapoca Rivers. Both are popular sites for beluga hunting and have proved to be practicable tagging sites, although the frequent hunting pressure makes belugas nervous and readily disturbed, and they are present only sporadically at either estuary (Kingsley, 2000). Belugas also occur in Richmond Gulf in summer.

\section{Capture and Tagging Procedures}

Belugas were caught in $40 \mathrm{~cm}$ stretch mesh nylon set nets at the Little Whale and Nastapoca Rivers in 1993. Net

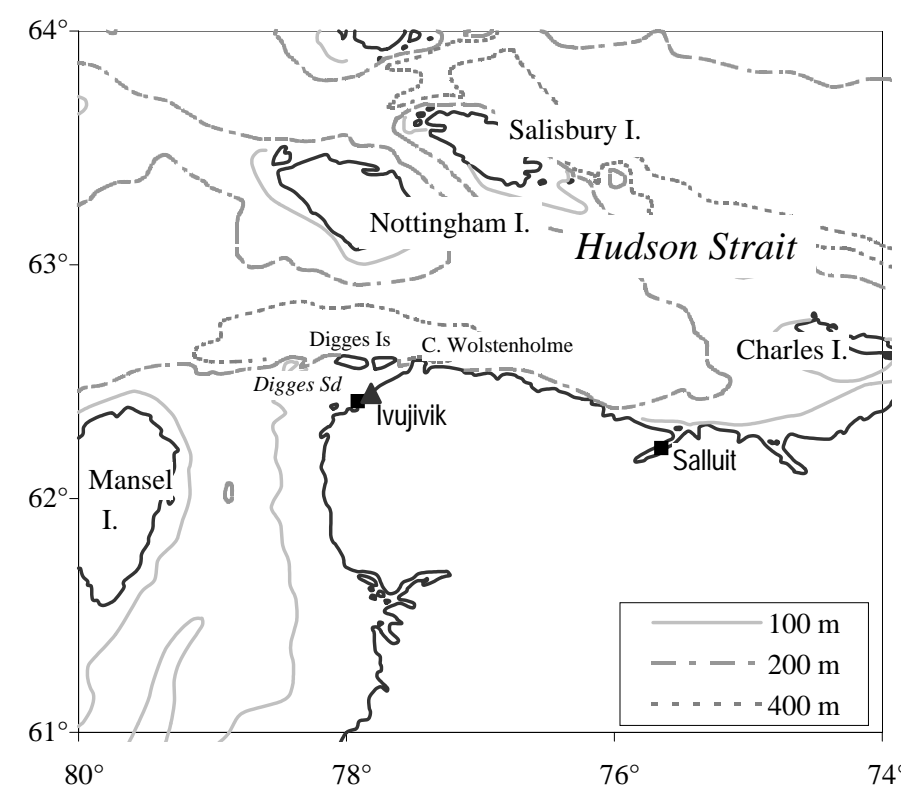

FIG. 2. Study area in northwestern Quebec and western Hudson Strait, Canada, showing $100 \mathrm{~m}, 200 \mathrm{~m}$, and $400 \mathrm{~m}$ isobaths. Black triangle indicates tagging site.

panels were $10 \mathrm{~m}$ long and initially $3 \mathrm{~m}$ deep, and two panels were used end to end. Nets were set perpendicular to the shoreline. At the Little Whale River, the net was set to extend from the northern headland of the mouth of the estuary to the west, in water less than $2 \mathrm{~m}$ deep. The nets were cut down appropriately. At the Nastapoca River, the net was set within the estuary, extending from the north shore partway across the channel.

In 1993, six belugas were tagged on the east coast of the Hudson Bay arc, and in late fall 1995 another was tagged near the northeastern tip of Quebec (Table 1). Tags were riveted to a saddle of neoprene-coated nylon fabric that was attached to the beluga by two $9 \mathrm{~mm}$ nylon dowels passed through the dorsal ridge. The dowels were drilled at $1 \mathrm{~cm}$ intervals and retained by $1.5 \mathrm{~mm}$ mild-steel split-pins.

\section{Data Collection, Management, and Analysis}

Data were stored in the tags and transmitted as counts of dives with different characteristics. Dives were defined as starting and ending when a threshold depth was transgressed. They were classified by the maximum depth reached and by how long they lasted. When each dive ended, it was assigned to a maximum-depth class and to a duration class and added to the counts for its depth and duration. Transmissions consisted of the counts of dives by depth class or by duration class in a $6 \mathrm{~h}$ period. Four of the six transmitters deployed in eastern Hudson Bay, as well as the one deployed in northeastern Hudson Bay in 1995, also transmitted data on the time spent within different depth bands. Dive depth and duration classes and depth bands for time-at-depth data were defined and programmed into the tags in advance. There was little prior information on the possible movements of belugas in these waters. Previous 
TABLE 1. Belugas tagged in eastern and northeastern Hudson Bay in 1993 and 1995.

\begin{tabular}{cccccr}
\hline \hline Service Argos Geolocation ID & \multicolumn{3}{c}{ Tagging coordinates } & \multirow{2}{*}{ Length (cm) } & Beluga was caught with (geolocation ID) \\
\cline { 2 - 4 } & Latitude (N) & Longitude (W) & Date & & 11747 \\
\hline $5090^{1}$ & $55^{\circ} 58^{\prime}$ & $76^{\circ} 12^{\prime}$ & $93-08-12$ & 390 & 11749 \\
$15091^{1}$ & $56^{\circ} 55^{\prime}$ & $76^{\circ} 32^{\prime}$ & $93-08-18$ & 265 & 5090 \\
11747 & $55^{\circ} 58^{\prime}$ & $76^{\circ} 12^{\prime}$ & $93-08-12$ & 280 & 11750 \\
11748 & $55^{\circ} 58^{\prime}$ & $76^{\circ} 12^{\prime}$ & $93-08-15$ & Adult $^{2}$ & 5091 \\
11749 & $56^{\circ} 55^{\prime}$ & $76^{\circ} 32^{\prime}$ & $93-08-18$ & 320 & 11748 \\
11750 & $55^{\circ} 58^{\prime}$ & $76^{\circ} 12^{\prime}$ & $93-08-15$ & 270 & none \\
\hline \hline
\end{tabular}

${ }^{1}$ Tags 5090 and 5091 had no time-at-depth records.

${ }^{2}$ adult, but active and tagged in rather deep water so not measured.

studies had found that belugas and narwhals often dive to the bottom (e.g., Martin and Smith, 1992; Martin et al., 1994) but that even in water $200 \mathrm{~m}$ deep, these normal dives seldom lasted more than 12-15 min. It was recognized that belugas would be in shallow water in eastern Hudson Bay, but it was not known when they would begin the fall migration that would take them into deeper water. Dive classes were designed to give good resolution on short (less than $10 \mathrm{~min}$ ) and shallow (less than $70 \mathrm{~m}$ ) dives, but some of the tags could store data on more dive classes and were programmed with depth classes extending to $220 \mathrm{~m}$. The tag deployed in northwestern Quebec in 1995 was programmed with depth classes to $400 \mathrm{~m}$.

Some animals' positional data were difficult to use because the locations were almost all of poor quality, and the apparent track was so erratic that it was difficult to decide which positions were reliable. In those cases, an initial track was generated from a moving average of the locations. An optimized track was then generated by altering the reported position coordinates while minimising a weighted total of the sum of squares of the estimated swimming speeds between fixes and the sum of squares of the adjustments to the positions. Positions that were adjusted by more than about $50 \mathrm{~km}$ in this process were progressively rejected. In this way, although accurate tracks were not obtained, approximate areas used over time could be defined. Five-point moving averages of latitude and longitude were calculated for plotting tracks.

For pairs of belugas tagged together, the degree to which their behaviour was coordinated was of interest. Five-point average positions were calculated, and the averages closest in time for the two animals were identified and plotted together. The dive behaviour of animals tagged together was compared using $6 \mathrm{~h}$ intervals as observational units. A maximum depth was available for each $24 \mathrm{~h}$ day, and this was also used to compare the behaviour of the two animals within a pair.

Of the tags deployed in 1993, \#5090 and \#5091 had no time-at-depth records, but recorded only the duration and maximum depth of dives. Total time spent deeper than $7 \mathrm{~m}$ (the dive threshold) was estimated from the number of dives in each duration class, assuming that the mean duration of dives in each class was equal to the class mid-point.
A daily rhythm in dive behaviour was sought by ranking, for each tagged animal, the mean time spent diving in each of the four $6 \mathrm{~h}$ periods composing the day. Apart from its biological interest, this question may affect application of dive data to correcting aerial surveys, which are flown in the daytime. A nonparametric test was used to determine whether the seven tagged belugas showed significant agreement in their daily patterns of behaviour.

\section{RESULTS}

\section{Eastern Hudson Bay_Movements and Dive Behaviour}

The belugas tagged in eastern Hudson Bay grouped into three pairs of animals that were tagged together. Two of the pairs appeared, from their dive data and movements, to remain associated, while the remaining two animals behaved independently. Overall average dive time varied from $30 \%$ of total time for the animals that dived least to $60 \%$ for the one that dived most (Table 2). Most dives were short. On average, only about $2 \%$ of dives lasted over 10 min, but the animal with the highest average dive time also made more long dives, $6 \%$ lasting over 10 min (Table 3 ). Different animals also had different distributions of dive depths: some dived intensively, apparently to the bottom, in 50-70 m of water, while others stayed mostly much nearer the surface but made occasional dives as deep as $100 \mathrm{~m}$ or more (Table 4).

Total dive time was estimated by summing dive durations, and for some tags also from the time-at-depth records for time spent deeper than $10 \mathrm{~m}$. The two estimates were well correlated, and estimating mean dive time by summing dive durations appears to be reliable. The relationship was close during intense diving, when little time was spent between $7 \mathrm{~m}$ and $10 \mathrm{~m}$ on the way down or up. It was also close when there was little diving activity and most time was spent above $7 \mathrm{~m}$ or in short dives. There was more scatter in periods of intermediate diving, when the time spent between 7 and $10 \mathrm{~m}$ was variable, and the maximum mean difference was about 15 percentage points. The mean overall difference was about 10 percentage points. 
TABLE 2. Proportion of time spent diving by seven belugas tagged in northern Quebec in 1993 and $1995 .{ }^{1}$

\begin{tabular}{|c|c|c|c|c|c|c|c|c|c|}
\hline \multirow[t]{2}{*}{ ID } & \multicolumn{9}{|c|}{ Mean (SE; number of periods; maximum) percentage of time spent diving ${ }^{2}$ in $6 \mathrm{~h}$ periods centred on: } \\
\hline & \multicolumn{2}{|l|}{ Midnight } & \multicolumn{2}{|l|}{6 a.m. } & \multicolumn{2}{|l|}{ Noon } & \multicolumn{2}{|l|}{6 p.m. } & Overall \\
\hline 5090 & 66.3 (2.4; 46; & 84) & $54.4(2.6 ; 44$ & 83) & $64.4(2.8 ; 45 ;$ & 86) & $55.7(2.7 ; 45$; & 83) & $60.3(1.4 ; 180 ; 86)$ \\
\hline 11747 & $56.0(4.0 ; 25$ & $81)$ & $57.1(3.7 ; 21 ;$ & $77)$ & $61.6(3.4 ; 25$ & $80)$ & 56.6 (3.4; 25; & $83)$ & $57.9(1.8 ; 96 ; 83)$ \\
\hline 11748 & $24.5(8.0 ; 10$ & $65)$ & $33.7(5.6 ; 12 ;$ & 64) & 34.5 (7.4; 12; & 72) & $23.4(5.3 ; 12 ;$ & 61) & $29.2(3.3 ; 46 ; 72)$ \\
\hline 11750 & $32.0(7.9 ; 11$ & $63)$ & $29.9(6.3 ; 11 ;$ & 69) & $35.1(12.7 ; 8$ & $83)$ & $20.2(7.7 ; 10 ;$ & $68)$ & $29.1(4.1 ; 40 ; 83)$ \\
\hline 11749 & $57.6(4.4 ; 14$ & 81) & $42.3(5.1 ; 16 ;$ & 73) & $54.0(5.8 ; 17 ;$ & $73)$ & $38.8(5.1 ; 17 ;$ & $84)$ & $47.8(2.7 ; 64 ; 84)$ \\
\hline 5091 & $49.7(4.8 ; 10$ & 72) & $60.4(4.1 ; 8 ;$ & 76) & $54.7(5.7 ; 12 ;$ & 72) & 56.7 (4.3; 13; & 78) & $55.2(2.4 ; 43 ; 78)$ \\
\hline 11751 & $60.7(2.8 ; 32$ & 86) & $59.5(2.1 ; 30$; & 76) & 53.7 (2.3; 32; & 73) & 53.9 (2.6; 31; & 73) & $56.9(1.3 ; 125 ; 86)$ \\
\hline
\end{tabular}

${ }^{1}$ The sums of ranks ( 1 = highest proportion of time spent diving) for 6 h periods were 16, 17, 14, and 23, respectively; i.e., most diving occurred around noon, least around 6 p.m. The coefficient of concordance (Kendall and Babington-Smith, 1939) $=0.184$ NS.

${ }^{2}$ For the first six belugas in this table, times are below $7 \mathrm{~m}$ from dive-duration records; for the last one, time is below $10 \mathrm{~m}$ from timeat-depth records. For three eastern Hudson Bay belugas for which records could be compared, time deeper than $10 \mathrm{~m}$ was about 10 percentage points less than time deeper than $7 \mathrm{~m}$.

TABLE 3. Distribution of the duration of dives by belugas tagged in eastern Hudson Bay in August 1993.

\begin{tabular}{|c|c|c|c|c|c|c|c|c|}
\hline \multirow[t]{2}{*}{ ID } & \multirow[t]{2}{*}{$\#$ of periods } & \multirow[t]{2}{*}{ \# of dives } & \multicolumn{6}{|c|}{ Percentage of dives below $7 \mathrm{~m}$ lasting (mins) } \\
\hline & & & $<1$ & $1-2$ & $2-4$ & $4-6$ & $6-10$ & $>10$ \\
\hline 5090 & 178 & 10878 & 40.7 & 8.7 & 13.1 & 12.9 & 18.4 & 6.2 \\
\hline 11747 & 96 & 5131 & 24.9 & 10.6 & 18.4 & 22.0 & 23.1 & 1.0 \\
\hline 11748 & 46 & 1852 & 43.6 & 14.1 & 18.0 & 12.3 & 10.3 & 1.7 \\
\hline 11750 & 40 & 1517 & 45.3 & 11.1 & 16.3 & 12.3 & 13.4 & 1.6 \\
\hline 11749 & 64 & 2778 & 30.0 & 8.0 & 15.9 & 16.5 & 29.0 & 0.6 \\
\hline 5091 & 43 & 2269 & 19.7 & 9.5 & 25.2 & 29.9 & 15.2 & 0.5 \\
\hline \multicolumn{3}{|c|}{ Mean distribution of dives } & 34.03 & 10.33 & 17.82 & 17.65 & 18.23 & 1.93 \\
\hline \multicolumn{3}{|c|}{ Estimated mean distribution of time } & $4.96 \%$ & $4.52 \%$ & $15.57 \%$ & $25.71 \%$ & $42.49 \%$ & $6.76 \%$ \\
\hline
\end{tabular}

TABLE 4. Distribution of dive depths for six belugas tagged in eastern Hudson Bay in August 1993.

\begin{tabular}{|c|c|c|c|c|c|c|c|c|}
\hline \multirow[t]{2}{*}{ ID } & \multirow[t]{2}{*}{ Number of dives } & \multicolumn{7}{|c|}{ Percentage of dives reaching depths $(\mathrm{m})$ of: } \\
\hline & & $7-10$ & $10-20$ & $20-30$ & $30-50$ & $50-70$ & $>70$ & $100-140$ \\
\hline 5090 & 2995 & 27.3 & 26.1 & 13.2 & 25.7 & 6.3 & 1.4 & $-{ }^{1}$ \\
\hline 11747 & 1096 & 23.5 & 25.9 & 14.9 & 30.4 & 5.2 & 0.1 & 0.0 \\
\hline 11748 & 1162 & 50.7 & 26.5 & 9.8 & 9.2 & 2.1 & 1.8 & 0.5 \\
\hline 11750 & 902 & 56.7 & 24.9 & 7.9 & 8.0 & 1.5 & 1.0 & 0.1 \\
\hline 11749 & 1156 & 35.6 & 11.5 & 3.8 & 13.7 & 20.7 & 14.7 & 3.2 \\
\hline 5091 & 490 & 20.9 & 24.8 & 31.1 & 7.9 & 10.7 & 4.7 & $-^{1}$ \\
\hline
\end{tabular}

${ }^{1}$ Tags \#5090 and \#5091 did not discriminate between dives deeper than $70 \mathrm{~m}$.

The first two belugas tagged in 1993 at the Little Whale River gave good results. The adult (\#5090) furnished data for seven weeks, transmitting an average of 550 messages per day, of which nearly $10 \%$ were received. The juvenile (\#11747) provided data for four weeks, transmitting 200 messages per day, of which $10 \%$ were received. The data record for both was nearly complete for the entire period of deployment.

Belugas \#5090 and \#11747 left the Little Whale estuary and headed to an area north and east of the Salikuaq Islands, between the mainland coast and the Belcher Islands, where the water is about $50 \mathrm{~m}$ deep. They stayed in a roughly crescent-shaped area measuring about $100 \mathrm{~km}$ from north to south and only about $30 \mathrm{~km}$ from east to west at any point (Fig. 3) for the entire period of record. The distribution of dive depths reflects the water depth. The proportion of time spent diving varied from one $6 \mathrm{~h}$ period to another, so distribution was smoothed with a moving average; however, even the smoothed curve showed periods of more intense and less intense diving (Fig. 4). There was no evident difference in the movement pattern or in the areas frequented between periods of more intense and less intense diving. When the whales spent a lot of time submerged, it was not because they made more dives in total (they made fewer; the correlation was negative) but because they made long, deep dives (Table 5).

Intense diving, which could last for several days, was characterized by 1) low variation in the proportion of time submerged, which remained high (60-80\%) for a number of consecutive $6 \mathrm{~h}$ periods; 2 ) few shallow or short dives; and 3) many deep and long dives. During less intense underwater 


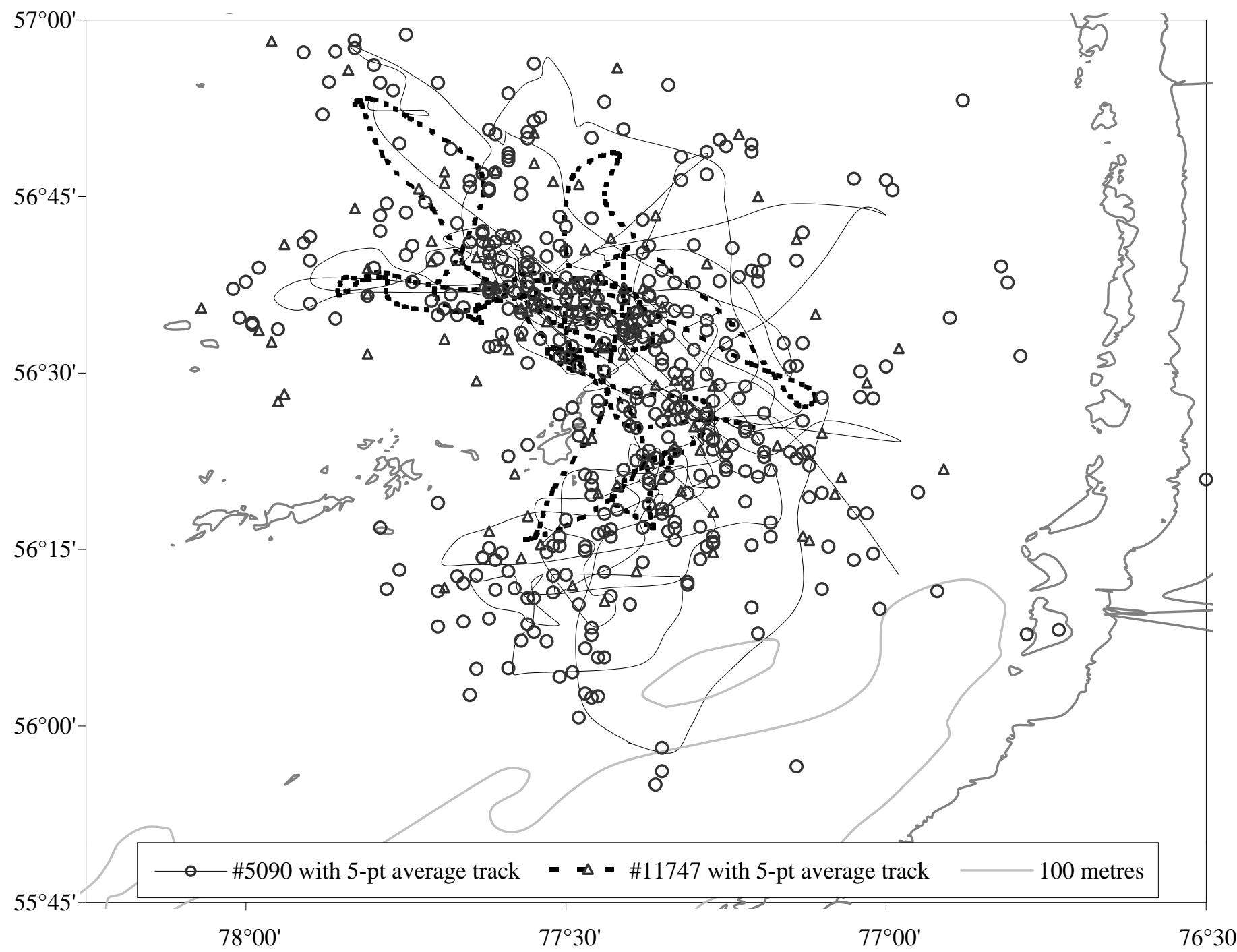

FIG. 3. Movements of an adult beluga (\#5090) and an associated juvenile (\#11747) tagged at the Little Whale estuary, eastern Hudson Bay, in August 1993.

activity, the proportion of time submerged varied much from one $6 \mathrm{~h}$ period to another (Fig. 4), and periods with little time at depth usually had many short, shallow dives.

These two animals appeared to stay together, and their dive behaviour was correlated. The $6 \mathrm{~h}$ periods were taken as observational units, and the dive time was estimated from the sum of dive durations. The correlation in dive time between the two animals was 0.87 . They had similar distributions of dive depths (Table 4). A co-location plot of averaged positions that were close in time showed coordinated movements, and their daily maximum dive depths were highly correlated $(\mathrm{R}=0.992$; Fig. 5$)$, indicating that they stayed close together. (However, \#11747 appeared to have a maximum dive depth that was consistently $10 \%$ less than that of \#5090. This was perhaps a systematically different behaviour of a younger animal, but-given the high correlation-might also have been due to error in the pressure sensor.) Estimated average dive time was $58 \%$ for the juvenile and $60 \%$ for the adult (Table 2).

Another pair of animals tagged together, \#11748 adult and \#11750 juvenile, had an even higher correlation of dive time: 0.988 for 22 six-hour periods that had data from both tags (Fig. 6). There was also a high correlation between the numbers of dives deeper than $30 \mathrm{~m}$ for the two animals. (There was no correlation between one pair and the other.) This may have indicated that they were a mother-calf pair, as beluga calves stay close to their mothers. The position data were erratic for both these animals, but especially for the juvenile. However, the very close correlation between the dive times indicated that the two were staying together, and a single track was established on the basis of the position data from both animals and optimized by adjusting the locations, minimizing the sums of squares of swimming speed and location adjustments. These two animals first went north in the Hudson Bay arc and then spent a short time in the neighbourhood of the Nastapoca River before returning to an inshore area between Richmond Gulf and the Manitounuk Islands (Fig. 7). They were still in this area when the tags stopped transmitting. They spent on average significantly less time diving than the other whales$27 \%$ for the adult and $25 \%$ for the juvenile — and most of 


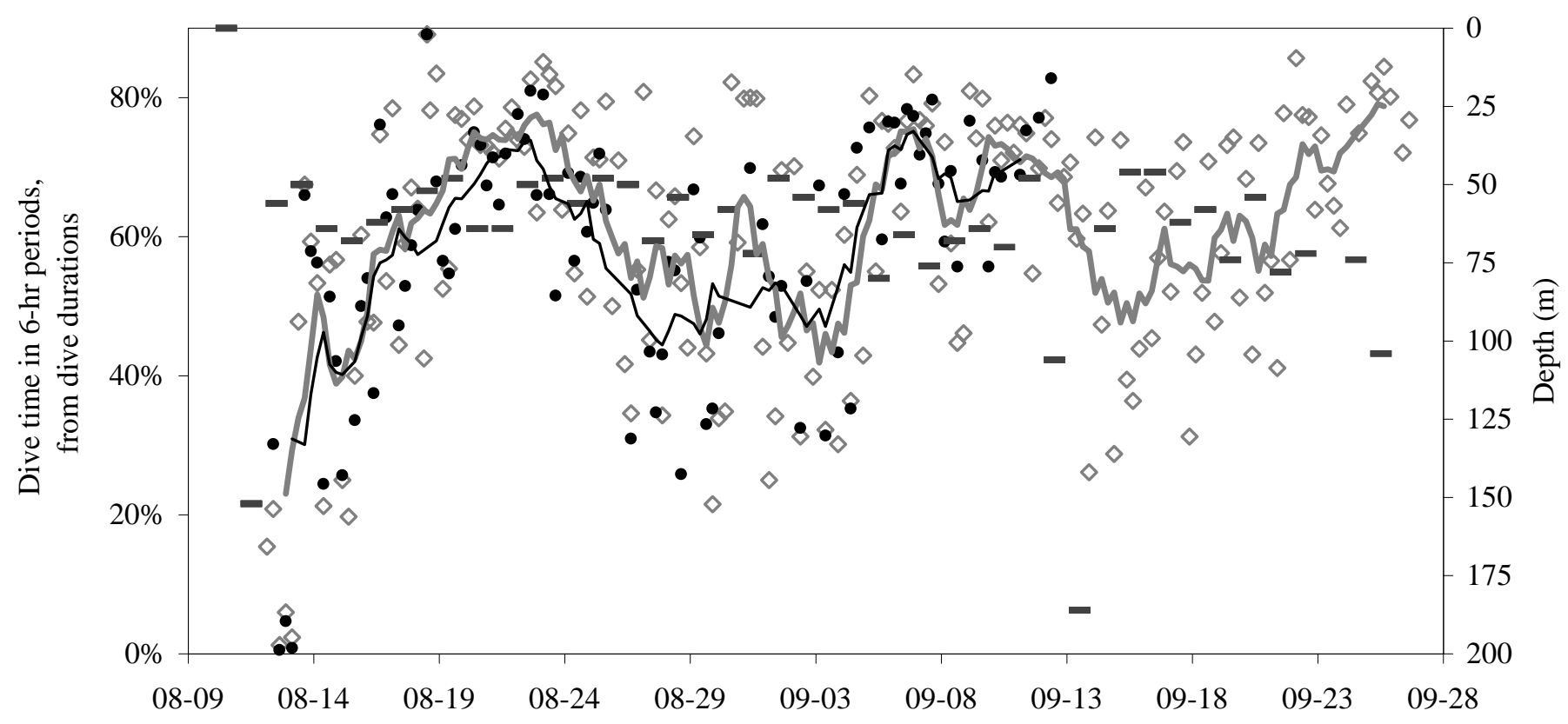

Date (1993)

$\leftarrow$ \#5090, dive time with 7-pt mean $\quad \longrightarrow \# 11747$, dive time with 7-pt mean $\quad$ - \#5090, daily maximum depth

FIG. 4. Dive time for an adult beluga (\#5090) and an associated juvenile (\#11747) tagged at the Little Whale estuary, eastern Hudson Bay, in August 1993.

TABLE 5. Correlation coefficients ${ }^{1}$ between numbers of dives in different time and depth classes during 181 six-hour periods by an adult beluga (\#5090) tagged at the Little Whale River, eastern Hudson Bay, in August 1993.

\begin{tabular}{|c|c|c|c|c|c|c|c|c|c|c|c|c|}
\hline & \multicolumn{6}{|c|}{ Dive depth class (m) } & \multicolumn{6}{|c|}{ Dive duration class (min) } \\
\hline & $<10$ & $10-20$ & $20-30$ & $30-50$ & $50-70$ & $>70$ & $<1$ & $1-2$ & $2-4$ & $4-6$ & $6-10$ & $<10$ \\
\hline$<10 \mathrm{~m}$ & & 0.62 & 0.29 & -0.04 & -0.22 & -0.12 & 0.90 & 0.40 & 0.21 & -0.10 & -0.36 & -0.35 \\
\hline $10-20 \mathrm{~m}$ & & & 0.61 & 0.01 & -0.30 & -0.21 & 0.77 & 0.59 & 0.45 & 0.19 & -0.38 & -0.52 \\
\hline $20-30 \mathrm{~m}$ & & & & 0.12 & -0.27 & -0.18 & 0.52 & 0.63 & 0.33 & 0.14 & -0.13 & -0.45 \\
\hline $30-50 \mathrm{~m}$ & & & & & -0.33 & -0.31 & 0.10 & 0.14 & -0.02 & 0.11 & 0.30 & 0.13 \\
\hline $50-70 \mathrm{~m}$ & & & & & & 0.20 & -0.24 & -0.23 & -0.17 & -0.04 & 0.35 & 0.21 \\
\hline$>70 \mathrm{~m}$ & & & & & & & -0.14 & -0.13 & -0.19 & -0.12 & 0.13 & 0.22 \\
\hline$<1 \mathrm{~min}$ & & & & & & & & 0.48 & 0.11 & -0.15 & -0.35 & -0.40 \\
\hline $1-2 \min$ & & & & & & & & & 0.48 & 0.00 & -0.37 & -0.37 \\
\hline $2-4 \min$ & & & & & & & & & & 0.40 & -0.33 & -0.40 \\
\hline $4-6 \min$ & & & & & & & & & & & 0.09 & -0.34 \\
\hline $6-10 \mathrm{~min}$ & & & & & & & & & & & & 0.16 \\
\hline Time below $7 \mathrm{~m}$ & -0.45 & -0.38 & -0.19 & 0.36 & 0.32 & 0.14 & -0.30 & -0.20 & -0.03 & 0.30 & 0.75 & 0.48 \\
\hline
\end{tabular}

${ }^{1}$ Approximate two-sided critical points for the correlation coefficient are 0.145 at $5 \%, 0.189$ at $1 \%$, and 0.239 at $0.1 \%$.

their dives were shallow and short, although they did make some deep dives to over $100 \mathrm{~m}$. They dived especially little in a five-day period from about 18 to 23 August (Fig. 8), which coincided with travelling about $100 \mathrm{~km}$ to the south from about $57^{\circ} \mathrm{N}$, off the Nastapoca River, to about $56^{\circ} \mathrm{N}$, off the Little Whale River. While they were off the Little Whale River, mean time deeper than $7 \mathrm{~m}$ was $36 \%$ for the adult.

For the remaining two animals tagged in 1993 (at the Nastapoca River), dive behaviour was not correlated, and overall mean dive time differed by about seven percentage points. Therefore, it is not likely that they were closely associated. The adult (\#11749) ranged widely into the northern part of the Hudson Bay arc. In eight days, it described an elongated one-and-a-half-circle path to the northwest, ending on the edge of the Belcher Islands plateau at about $57^{\circ} 00^{\prime} \mathrm{N}, 77^{\circ} 30^{\prime} \mathrm{W}$; i.e., just to the north of the area heavily used by \#5090 and \#11747 (Fig. 7). It stayed there for about 12 days and then seemed to start moving quite fast, again toward the northwest. It was at $58^{\circ} 30^{\prime} \mathrm{N}$ when transmissions stopped on 17 September. There was no evident correlation between its dive behaviour and its movements. However, its dive behaviour was always rather variable, and it never dived intensively for a 


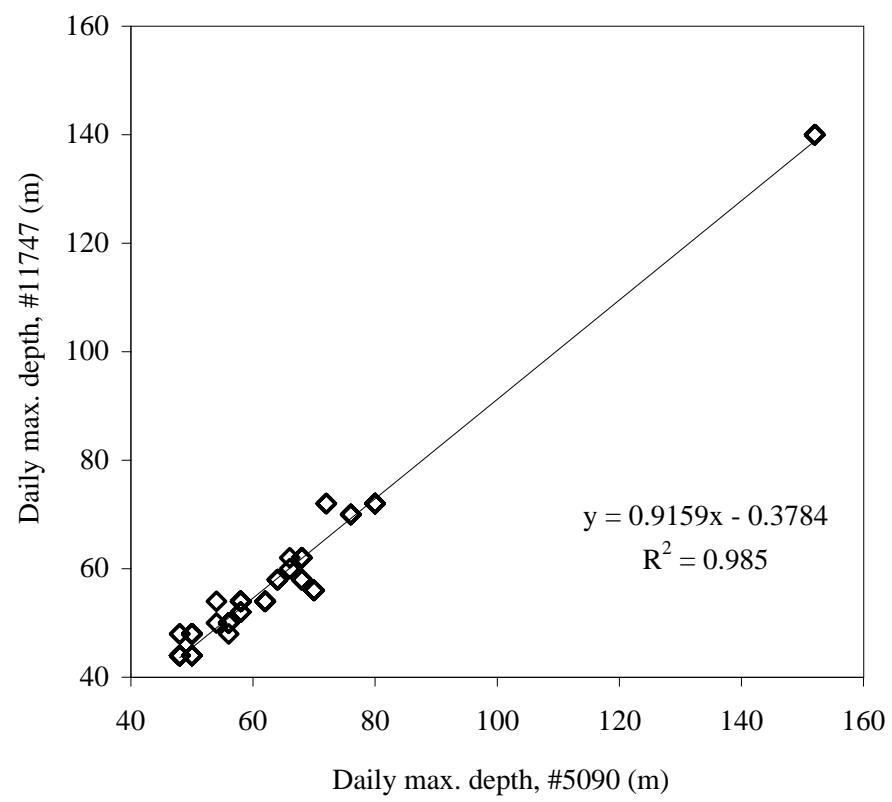

FIG. 5. Relationship between daily maximum depths for two belugas, an adult (\#5090) and an associated juvenile (\#11747), tagged at the Little Whale estuary, eastern Hudson Bay, in August 1993.

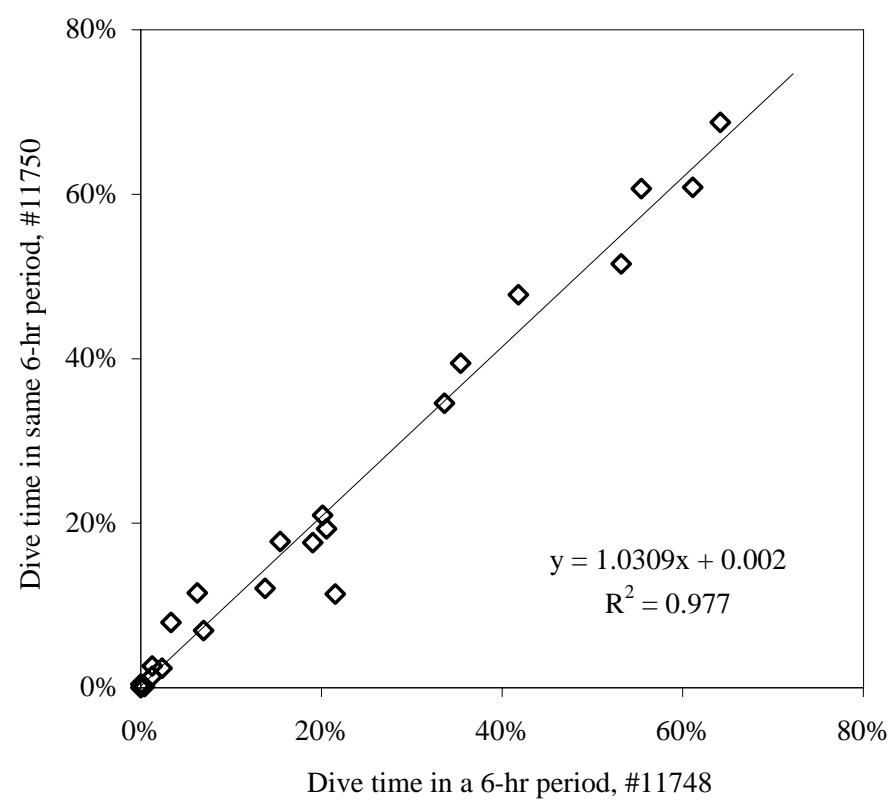

FIG. 6. Relationship between dive times for two belugas, an adult (\#11748) and a closely associated juvenile (\#11750), tagged at the Little Whale estuary, eastern Hudson Bay, in August 1993.

sustained period (Fig. 9). The juvenile tagged at the Nastapoca (\#5091) gave few positions, but its mean track also appeared to be well offshore, on the northeastern edge of the Belcher Islands plateau.

\section{Northwestern Quebec-Movements and Dive Behaviour}

Beluga \#11751 was tagged in mid-October 1995 near Ivujivik and retained the tag for a month. This whale went out to the middle of the channel between the mainland and

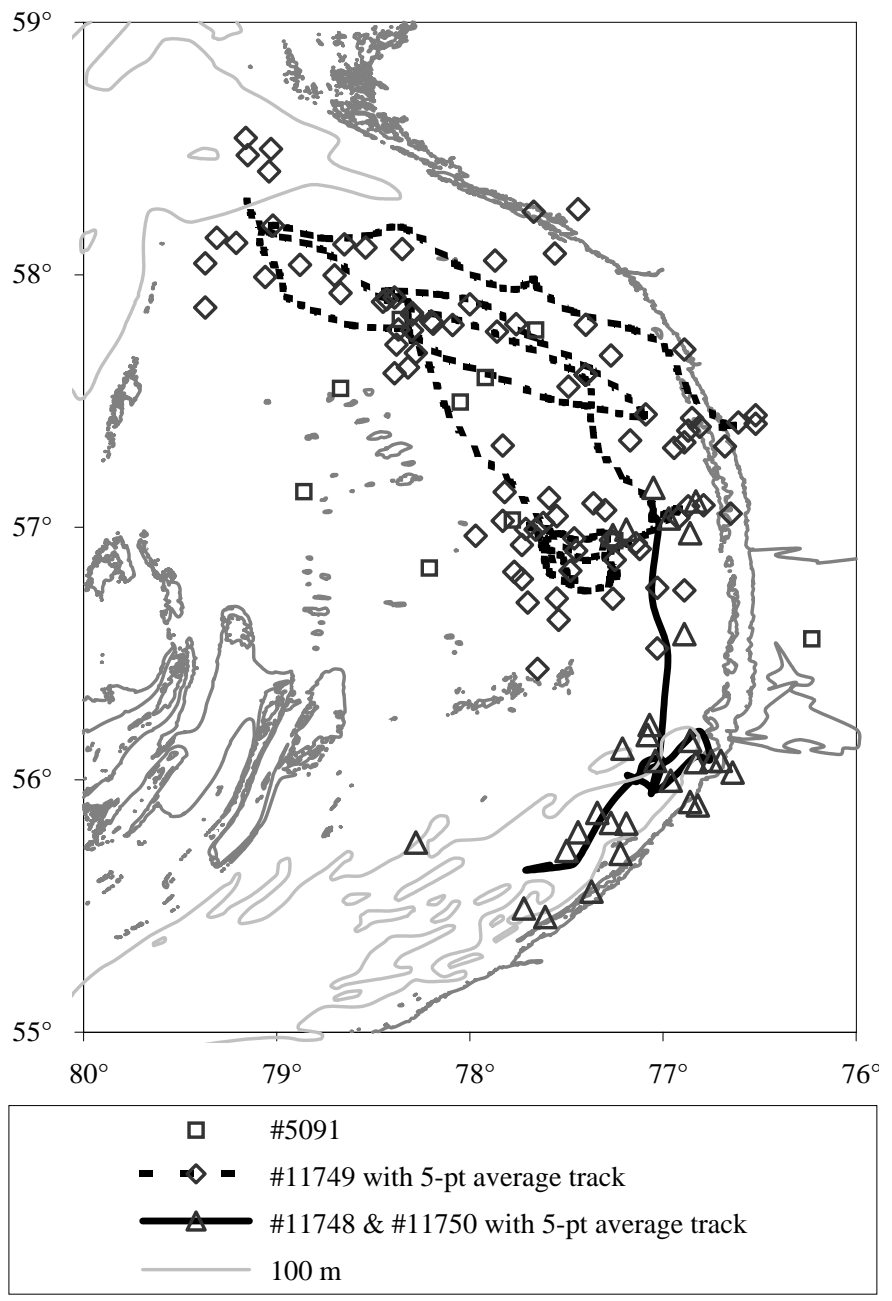

FIG. 7. Movements of belugas (\#11748 and \#11750) tagged at the Little Whale estuary and of an adult (\#11749) and a juvenile (\#5091) beluga tagged at the Nastapoca estuary, eastern Hudson Bay, in August 1993.

Mansel Island. It stayed in water deeper than $100 \mathrm{~m}$, travelling first to the south of Ivujivik, and was at about $62^{\circ} \mathrm{N}$ until the afternoon of 22 October. Dive depths were variable during this period, but it is not known whether the beluga was making mid-water dives or diving always to the bottom in water of varying depth. The daily maximum depth was roughly constant at 200-240 m (Fig. 10). After 23 October, this whale started moving north toward Hudson Strait, and it crossed the $200 \mathrm{~m}$ isobath into Hudson Strait after noon on 24 October. The underwater cliff bounding southern Hudson Strait was shown in the daily maximum depths, which abruptly changed from $220 \mathrm{~m}$ to nearly $500 \mathrm{~m}$ (Fig. 10). From that time on, while in the deep water of Hudson Strait, the whale continued its intense diving, spending about $30 \%$ of its time at depths over $200 \mathrm{~m}$ (Table 6, Fig. 11). This increase in dive depth was accompanied by a small increase in the proportion of time spent at depths less than $10 \mathrm{~m}$, from less than $40 \%$ to over $50 \%$. After that, through the end of October and through to the middle of November, the time spent near the surface gradually decreased. 


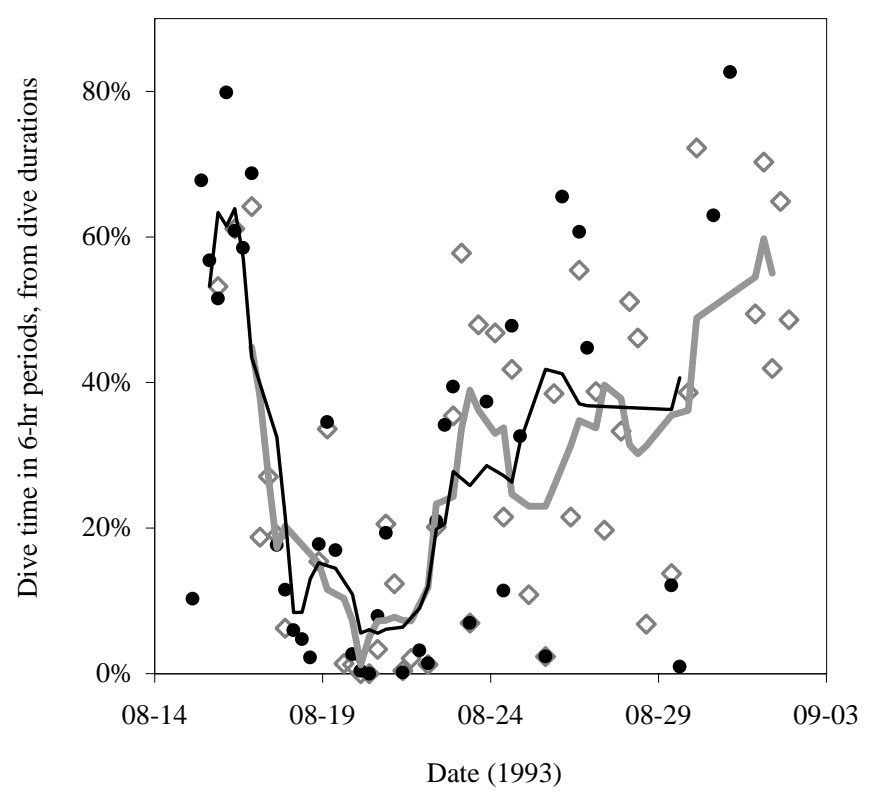

\#11748 with 5-pt mean

$\longrightarrow$ \#11750 with 5-pt mean

FIG. 8. Dive times for an adult beluga (\#11748) and a closely associated juvenile (\#11750) tagged at the Little Whale estuary, eastern Hudson Bay, in August 1993.

The maximum dive time for \#11751 was about $75 \%$, as was the case for the eastern Hudson Bay belugas and for the belugas whose diving behaviour was recorded in the eastern Canadian High Arctic in fall (Heide-Jørgensen et al., 1998). During periods of intense diving, this maximum level was maintained for several consecutive $6 \mathrm{~h}$ periods. In periods of less intense diving, values similar to this sometimes occurred, but they were not maintained.

Whale \#11751 travelled east to the end of the nearshore deep-water channel, off Salluit (Fig. 12), and arrived there on about 31 October. While travelling east in the deep water of Hudson Strait, it spent $20 \%$ of its time at depths greater than $300 \mathrm{~m}$ and made up to 27 dives deeper than $350 \mathrm{~m}$ in a $6 \mathrm{~h}$ period. The whale stayed close to the mainland coast, which is steep-to, and avoided the shallower water near Nottingham and Salisbury Islands. The easterly movement seemed to be terminated and constrained by the $200 \mathrm{~m}$ isobath and the whale's apparent reluctance to move into the shallower water between Charles Island and the mainland (Fig. 12). Diving deeper than $300 \mathrm{~m}$ stopped abruptly on 2 November, when the whale was northeast of Salluit. The whale then spent the first two weeks of November off the mouth of Salluit fjord, without large movements, diving to between $200 \mathrm{~m}$ and $300 \mathrm{~m}$. On 15 November, it recommenced intensive diving to $300 \mathrm{~m}$ and beyond, spending $22 \%$ of its time below that depth, and this behaviour continued until the tag stopped transmitting on 20 November.

Throughout this whale's time in Hudson Strait, most of its dives were deep (Table 6). A typical $6 \mathrm{~h}$ period might include as many as 30 dives, all deeper than $350 \mathrm{~m}$, and no dives to intermediate depths. In about $14 \%$ of periods spent in Hudson Strait, the pattern was less regular, with

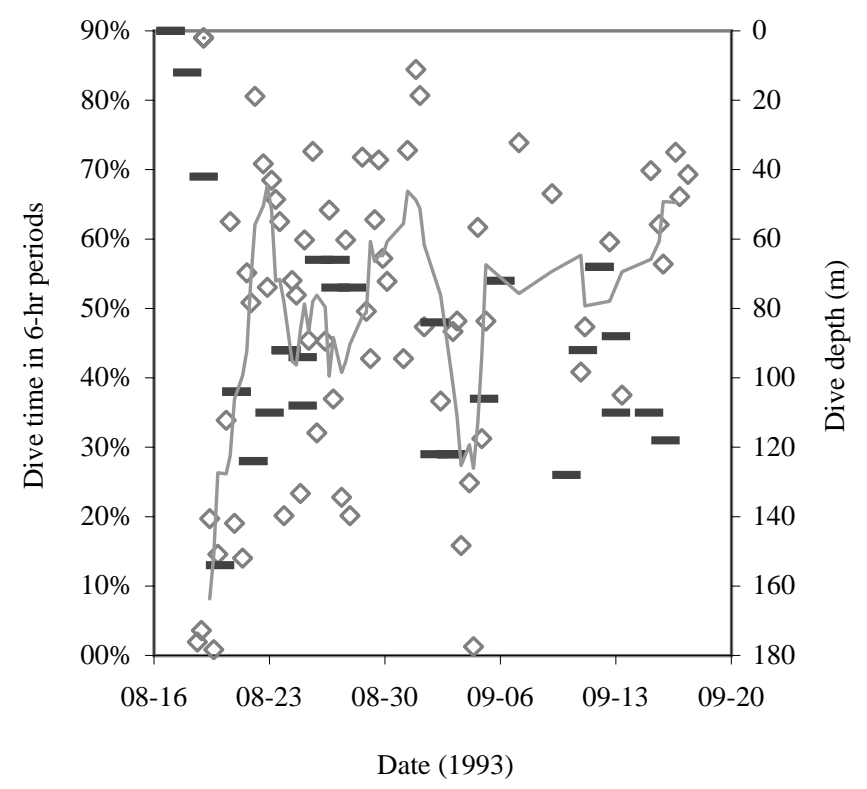

- Daily maximum depth $(\mathrm{m}) \quad \diamond$ Dive time with 5-pt mean

FIG. 9. Dive behaviour of an adult beluga (\#11749) tagged at the Nastapoca River, eastern Hudson Bay, in August 1993.

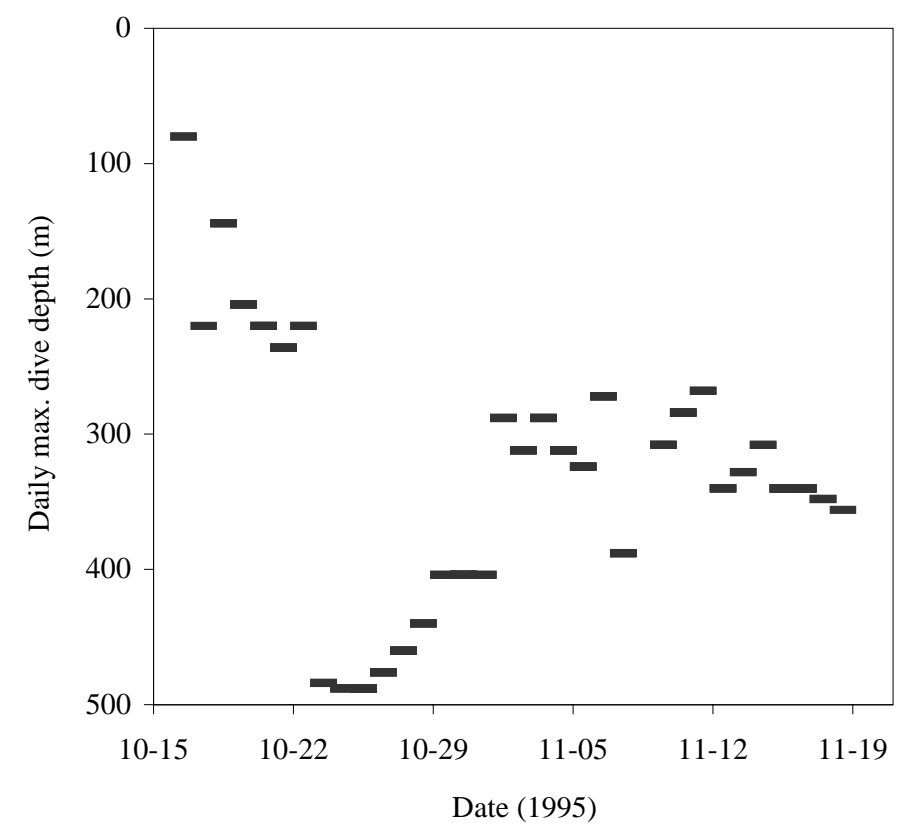

FIG. 10. Daily maximum dive depths for a beluga (\#11751) tagged near Ivujivik in northwestern Quebec in mid-October 1995.

dives to many different, shallower levels. In such cases, even though there were a number of different destination depth bands within a $6 \mathrm{~h}$ period, there was usually a clear modal depth band-60, 80 , or $140 \mathrm{~m}$-but it seemed to vary from one period to another, and there was no stable middle depth to which the beluga often dived.

To estimate vertical speed, we selected $6 \mathrm{~h}$ periods in which all dives were either shallower than $50 \mathrm{~m}$ or deeper than $300 \mathrm{~m}$. All of the 12 such periods would be considered 
TABLE 6. Distribution of the depths of 2261 dives below $20 \mathrm{~m}$ by an adult female beluga (\#11751) tagged near Ivujivik in northwestern Quebec in October 1995.

\begin{tabular}{lcccccr}
\hline \hline \multirow{2}{*}{ Area of movements } & \multirow{2}{*}{ Mean dives/h } & \multicolumn{4}{c}{ Percentage of dives reaching depths (m) of: } \\
\cline { 3 - 6 } & & $20-30$ & $30-60$ & $60-100$ & $100-200$ & $200-400$ \\
\hline NE Hudson Bay & 36.1 & 22.9 & 21.7 & 7.7 & 38.5 & 9.3 \\
W Hudson Strait & 29.8 & 2.2 & 3.4 & 4.5 & 13.1 & 76.2 \\
\hline \hline
\end{tabular}

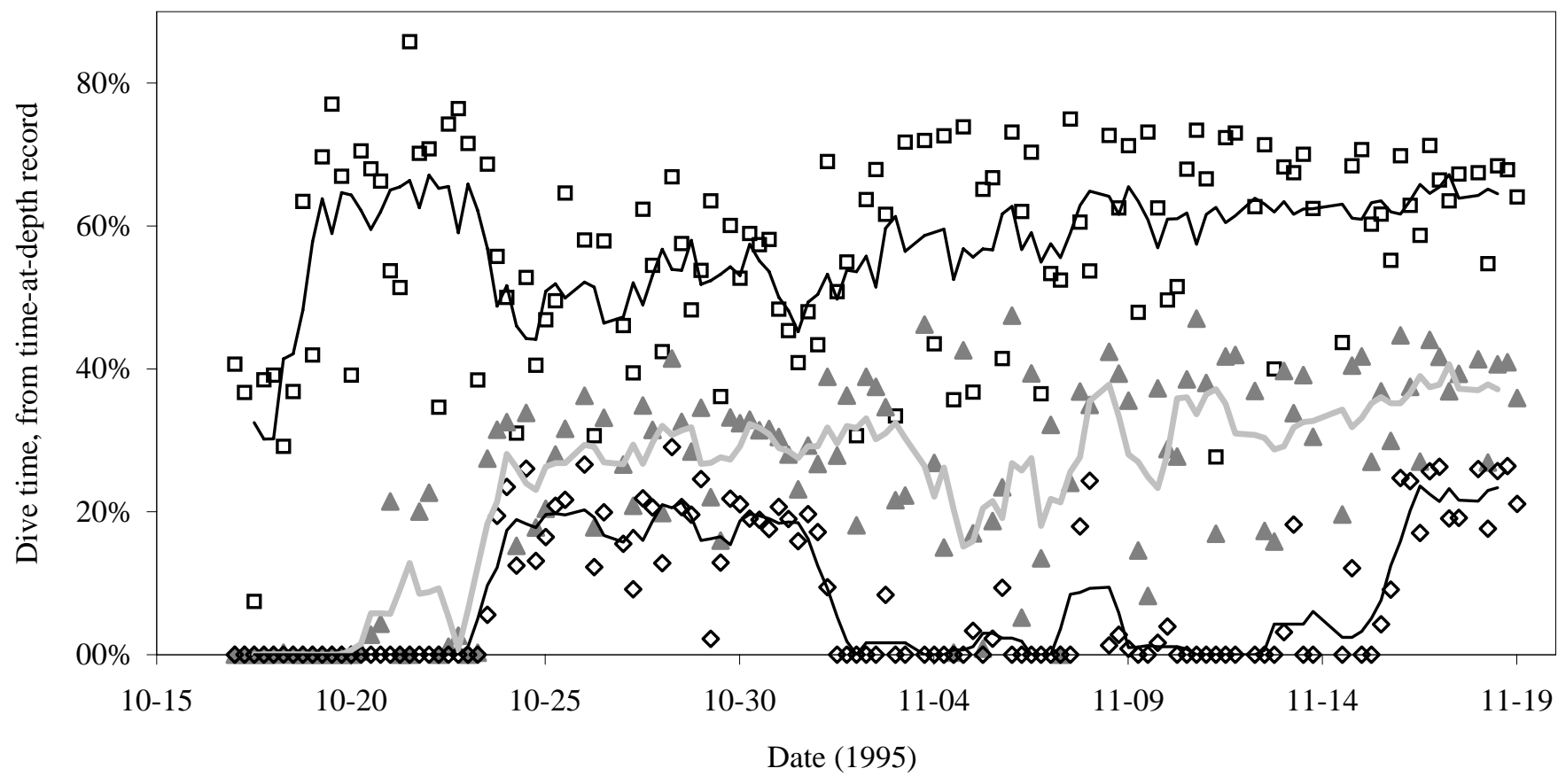

ㅁ Deeper than $10 \mathrm{~m}$, with 5-pt mean

$\triangle$ Deeper than $200 \mathrm{~m}$, with 5-pt mean

$\diamond$ Deeper than $300 \mathrm{~m}$, with 5-pt mean

FIG. 11. Dive behaviour of a beluga (\#11751) tagged near Ivujivik, northwestern Quebec, in mid-October 1995.

'intensive diving' periods; they comprised 321 dives and averaged $60 \%$ (SD 7\%) of time deeper than $10 \mathrm{~m}$ and $22 \%$ deeper than $300 \mathrm{~m}$. The vertical distance travelled through depth bands (50-100 m, 100-150 m, 150-200 m, and 200$300 \mathrm{~m}$ ) was calculated from the number of deep dives, and the time spent transiting each depth band was reported by the tag in time-at-depth records. When diving deeper than $350 \mathrm{~m}$, the beluga transited all depth bands faster than when diving only to $300-350 \mathrm{~m}$. The fastest transits, averaging $2.19 \mathrm{~m} / \mathrm{sec}$ (SE $0.028 \mathrm{~m} / \mathrm{sec}$ ), were between $100 \mathrm{~m}$ and $200 \mathrm{~m}$ on dives deeper than $350 \mathrm{~m}$; the overall average between $50 \mathrm{~m}$ and $300 \mathrm{~m}$ on such dives was $2.14 \mathrm{~m} / \mathrm{s}(\mathrm{SE} 0.022 \mathrm{~m} / \mathrm{s})$. When diving to maximum depths of $300-350 \mathrm{~m}$, the beluga averaged $1.99 \mathrm{~m} / \mathrm{s}(\mathrm{SE} 0.025 \mathrm{~m} / \mathrm{s})$ between $50 \mathrm{~m}$ and $200 \mathrm{~m}$.

Whale \#11751 combined deep diving with steady travel east in Hudson Strait and then combined shallower diving with a stay in a restricted area off Salluit. A further episode of deep diving was then associated with a period during which the whale remained stationary. The dive behaviour could not be matched with more or less rapid directional movement: there was no indication that the whale stayed close to the surface while travelling.

\section{DISCUSSION AND CONCLUSIONS}

Combining recorded dive behaviour with information on the depth to which animals can be seen by airborne observers is one way to estimate a correction factor for aerial surveys. Obtaining a reliable quantitative estimate is difficult, as it depends not only on the behaviour of the whales, but also on the survey platform, the observers' search pattern, and the ranges at which observations are recorded.

When models of monodontids were photographed from the air at 1:6000 in northwestern Hudson Bay, adult models could be seen, indistinctly, as deep as $10 \mathrm{~m}$ (Richard et al., 1994). In the St. Lawrence, full-sized models of adult belugas, photographed vertically at a scale of 1:8000, could be seen to the same depth as a Secchi disc, which in the clearest water was $11 \mathrm{~m}$. A visual observer could see beluga models almost exactly as well as a photo interpreter (Gauthier, 1999). Young grey animals were visible to only half the depth at which adults could be seen, or even less (Richard et al., 1994; Gauthier, 1999).

In visual aerial surveys from aircraft with flat or shallow-bubble windows, observations are usually made at 


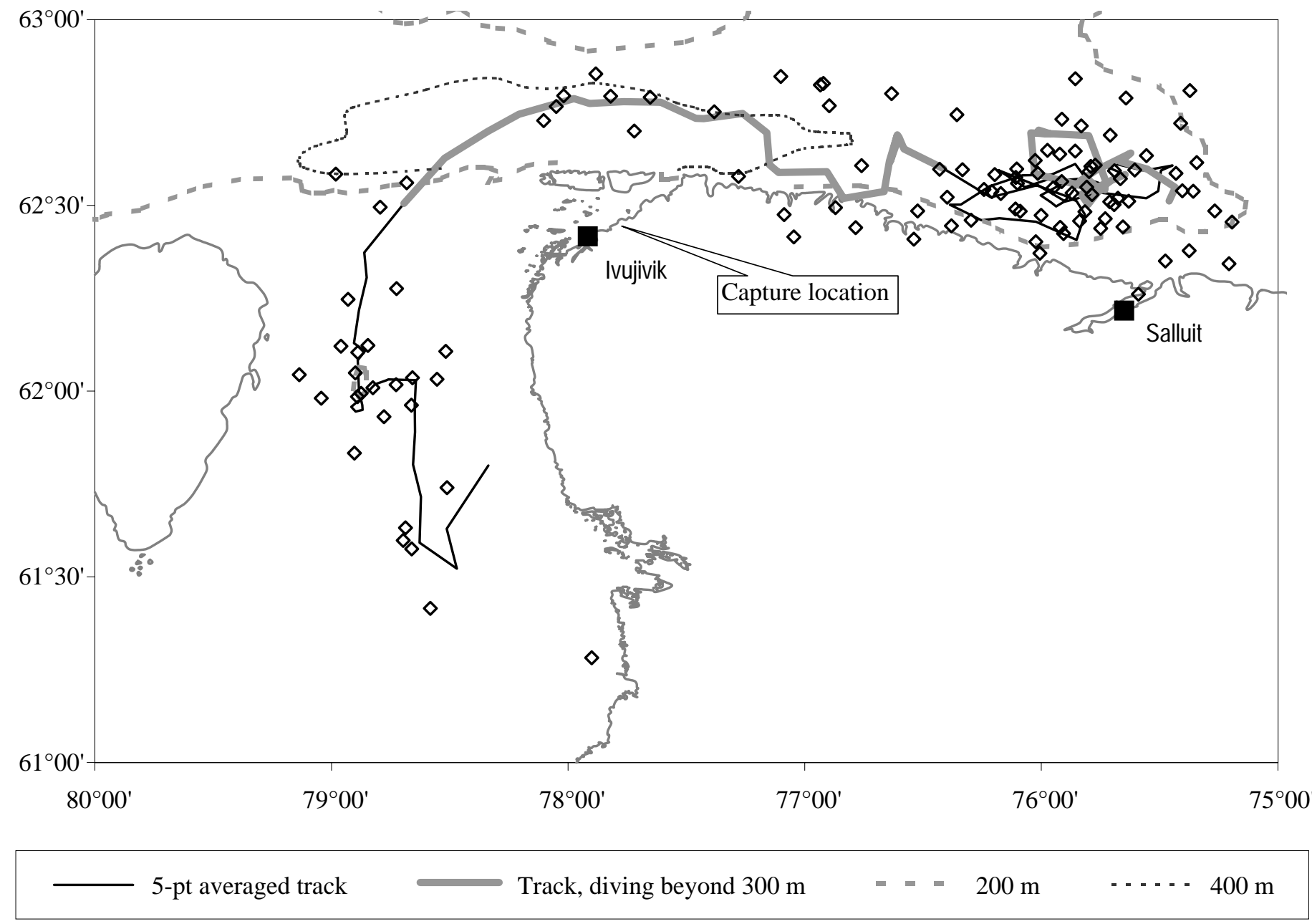

FIG. 12. Movements up to mid-November 1995 of a beluga (\#11751) tagged near Ivujivik, northwestern Quebec, in mid-October.

angles less than $55^{\circ}$ below the horizontal, especially when line-transect methods are used (Larsen et al., 1994; Harwood et al., 1996; Kingsley, 2000). Maximum counts are recorded at angles near $45^{\circ}$ using some platforms (Kingsley and Reeves, 1998; Kingsley, 2000). View angles from a visual aerial survey for belugas in eastern Hudson Bay were analyzed; they were so oblique that if belugas had been $7 \mathrm{~m}$ below the surface, $25 \%$ would have been seen through 7-10.9 m of water, 25\% through 10.9-13.6 m, 25\% through $13.6-18 \mathrm{~m}$, and $25 \%$ through more than $18 \mathrm{~m}$. Visibility of belugas through the water is relevant for those animals that are close to the track line, in sight for a short period, and apt to be recorded while submerged. Submerged animals far out are not likely to be detected or counted by transparency, but they remain longer within an observer's visible field (Hain et al., 1999) and may be detected when they surface to breathe. In ventilation sequences between deep dives, belugas usually remain close to the surface and breathe every $12-15$ seconds. Belugas close to the surface may be counted by transparency when close to the track line and on surfacing if farther out.

If line-transect methods are used to analyze survey data, the complexities of distance-dependent correction factors disappear. In line-transect analysis, the overall estimate of density depends on observations made in the full-visibility strip and only correction factors for those observations are relevant: relative correction factors at other distances are subsumed in the curve of relative visibility that is fitted to the observations in a line-transect analysis. In a linetransect aerial survey of belugas in James Bay and eastern Hudson Bay (Kingsley, 2000), the relative visibility exceeded $95 \%$ only between 430 and $703 \mathrm{~m}$ from the track line, corresponding to sighting angles of $47^{\circ}-33^{\circ}$ from the horizontal. Over that range, whales seen through $11 \mathrm{~m}$ of water would be at an average depth of $6.94 \mathrm{~m}$, so $7 \mathrm{~m}$ is an appropriate depth limit when considering correction factors for aerial sighting surveys similar to that one. Such a correction factor might still be conservative (i.e., it might underestimate the true numbers) because looking straight down through $11 \mathrm{~m}$ of water is not the same thing as looking obliquely with sunlight or sky-light reflected from the surface, distortion by waves, and so on.

Martin and Smith (1992) estimated from tag data for belugas in the central Canadian High Arctic that about $42 \%$ should be added to counts, but higher corrections were estimated for belugas tagged in the eastern Canadian High 
TABLE 7. Distribution of the durations of 3750 dives below $20 \mathrm{~m}$ by an adult female beluga (\#11751) tagged near Ivujivik in northwestern Quebec in October 1995.

\begin{tabular}{lcrrr}
\hline \hline Area of movements & \multirow{2}{*}{ Mean dives/h } & \multicolumn{3}{c}{ Percentage of dives lasting (min): } \\
\cline { 3 - 5 } & & $<-8$ & $8-10$ & $10-12$ \\
\hline NE Hudson Bay & 36.4 & 83.7 & 13 & 2.5 \\
W Hudson Strait & 28.1 & 67.6 & 29.2 & 3.0 \\
\hline \hline
\end{tabular}

${ }^{1}$ No dives lasted more than 14 min below $20 \mathrm{~m}$.

Arctic in fall (Heide-Jørgensen et al., 1998). Belugas observed directly from a helicopter in the more turbid waters of the St. Lawrence estuary were visible $44 \%$ of the time, and it was estimated that over $100 \%$ should be added to survey counts (Gauthier, 1999). In the present study, an average visibility correction was estimated by treating each beluga as a single independent observation, and the reciprocal of the mean time visible was corrected for its bias as a visibility correction factor. The estimated correction, based on dive times below $7 \mathrm{~m}$, was about $85 \%$ (SE 20\%) to be added to survey counts. This correction factor was based on the overall proportion of time visible. Belugas dived less in $6 \mathrm{~h}$ periods centred on noon-the period when aerial surveys are most likely to be flown - than at other times, but the difference was not statistically significant (Table 2).

Tagged belugas belonging to the eastern coastal summering stock made use of offshore areas in eastern Hudson Bay that extended into the eastern end of both the Nunavut Settlement Area and the Equal Use and Occupancy Area defined in the Nunavut Final Agreement (Anonymous, 1993). Summer beluga hunting, at least in the eastern part of these areas, should therefore be managed jointly. On the other hand, there was no evidence from movements of tagged animals that belugas from the eastern coastal summering areas travelled as far to the west as the Belcher Islands. In a 1993 aerial survey, observations were moderately continuous out into the Belcher Islands, and there was no evident discontinuity in distribution (Kingsley, 2000). However, the present tagging results, as well as analyses of natural tags (NAMMCO, 2000), appear consistent with the hypothesis that belugas counted in the Belcher Islands do not form part of the eastern coastal stock.

There was some slight evidence that the belugas tagged in the Little Whale River and those tagged in the Nastapoca River used different offshore areas. The Little Whale belugas mostly stayed, and dived intensively, in areas south of about $57^{\circ} \mathrm{N}$, but the one tagged in the Nastapoca River seemed to use areas north of $57^{\circ} \mathrm{N}$. Studies of belugas in Hudson Bay, Alaska, the White Sea, and southern Davis Strait (southeast Baffin Island) all seem to confirm earlier suggestions of fidelity to particular estuaries (Caron and Smith, 1990) and support the hypothesis of a finely divided population structure in this species (NAMMCO, 2000).

The animals tagged in pairs at the Little Whale River remained associated over periods of weeks. For one of the pairs, this association appeared to extend to the level of dive behaviour, as revealed by high correlations of dive times and numbers of dives. The position data were not good enough to measure the surface spatial relationship between these animals. Young belugas stay close to their mothers, and in aerial photographs of belugas taken for population census surveys in the St. Lawrence and elsewhere, closely associated beluga pairs can be seen underwater to the limit of visibility. However, often the members of more loosely associated groups also display a considerable measure of coordination in diving and resurfacing. The moderately high correlation in dive times in the first pair was probably consistent with membership in a common group, while the significantly higher correlation between the members of the second pair might have indicated a female accompanied by a younger, more dependent calf.

Dives were short. Few lasted longer than $10 \mathrm{~min}$, and very many lasted less than $1 \mathrm{~min}$ (Table 3 ). This is surprising in view of the known capacity of belugas to make longer dives: Richard et al. (1997) describe the typical dive in water deeper than $15 \mathrm{~m}$ as lasting between 10 and $20 \mathrm{~min}$. The partitioning of dive time is of course different, and nearly $50 \%$ of dive time is spent in dives that last over $6 \mathrm{~min}$. A beluga travelling at $2 \mathrm{~m} / \mathrm{s}$ reaches the seabed at $60 \mathrm{~m}$ in 30 seconds and can spend about $84 \%$ of a $6 \mathrm{~min}$ dive at the bottom. Extending the total length of the dive by $67 \%$ to $10 \mathrm{~min}$ increases this ratio to $90 \%$, i.e., by only $7 \%$, so a dive lasting 6-10 min may be so efficient that there is not much reason to dive for longer than that. Short dives may be efficient in shallow water.

Beluga \#11751, tagged in 1995, spent much time in water much deeper than that of eastern Hudson Bay. Diving to the bottom was indicated in this case, as in others, although what resource was being sought at those depths was unknown. This beluga dived deep while it was travelling and did not seem to stay on or close to the surface to travel. But its dives, even in such deep water, did not last much longer than those of the other belugas in the shallow water of eastern Hudson Bay (Table 7). The proportion of dives longer than $10 \mathrm{~min}$ was greater, because the increase of the dive threshold to $20 \mathrm{~m}$ eliminated a lot of short, shallow dives (which in the data records with a $7 \mathrm{~m}$ threshold accounted for many dives, but not much time). When this beluga moved into the deeper water of Hudson Strait, the proportion of dives lasting less than 8 min decreased, but the corresponding increase was principally in dives lasting $8-10 \mathrm{~min}$. The proportion of dives lasting over 10 min remained small (Table 7), and the 
proportion of dive time spent in dives over 10 min was about $6 \%$. Less than half of dive time was used to make dives over $8 \mathrm{~min}$ long, and only a negligible proportion of both dives and dive time was allocated to dives over $12 \mathrm{~min}$. No dives lasted longer than $14 \mathrm{~min}$. Even at $300 \mathrm{~m}$, a beluga diving at $2 \mathrm{~m} / \mathrm{s}$ still has $50 \%$ bottom time on a $10 \mathrm{~min}$ dive, and $38 \%$ bottom time on an 8 min dive. In spite of seldom diving for more than $10 \mathrm{~min}$, \#11751 averaged over $20 \%$ of several $6 \mathrm{~h}$ periods at depths over $300 \mathrm{~m}$; this composed $36 \%$ of the time below $10 \mathrm{~m}$.

Belugas tracked in the Canadian High Arctic and the western Canadian Arctic have been found to move from the freshwater estuaries where they congregate in early summer to distinct late-summer congregation areas in deep water, where sustained diving activity has been thought to imply intensive feeding (Smith and Martin, 1994; Richard et al., 1997). In some cases, these areas were either not known to be frequented by belugas, or not associated with the summering group that was found to go there. Some of these movements indicate sexual segregation, males in particular favouring remote deep areas (Richard et al., 1997). From aerial survey data, it appears that narwhals also favour deep-water areas (Richard et al., 1994; Kingsley et al., 1994). The only remotely similar phenomenon apparent from the eastern Hudson Bay data is an apparent tendency to use the eastern point of the Belcher Islands plateau, where three of the five tracked animals spent time without moving very much. However, this is not at all a deep-water area, being only about $50 \mathrm{~m}$ deep.

The composite tagging data provide no clear or comprehensive picture of the fall migration or timing. The animals tagged in eastern Hudson Bay showed no sign of starting to migrate by the end of the third week of September, while by mid-October belugas (of an unknown stock) were present near the Digges Islands (a number were taken by hunters on W. Digges Island at that time). Conclusions from \#11751 are tentative, but it travelled quite directedly from Digges Sound to Salluit, where it apparently stopped directed travel to stay in a restricted area. Belugas are thought to winter throughout Hudson Strait, which does not consolidate in winter, and concentration areas have not been identified. It is not clear whether, or when, \#11751 would have made further progress eastward. However, it seems that the movement from eastern Hudson Bay to northwestern Quebec could take place between mid-September and mid-October. The same belugas could be hunted at Ivujivik on their fall migration and again a few weeks later at Salluit. This potential load on the eastern Hudson Bay stock could be mitigated if there were evidence that large numbers of belugas from the western Hudson Bay stock are present in the southern part of western Hudson Strait during these hunting seasons, or that they form a major proportion of the catches. But such indications are so far lacking.

The results reported here indicate it is not likely that belugas counted near the Belcher Islands in summer aerial surveys in 1985 and 1993 formed part of the eastern
Hudson Bay coastal stock. Careful management of harvests at estuaries along the eastern Hudson Bay coast is indicated. Furthermore, it now appears even more likely that migration of the coastal stock exposes it to being hunted by several communities along its route.

Intensive diving, usually to the bottom, is a normal behaviour pattern for belugas, at times even while they are travelling. Detection rates in aerial surveys are likely to be close to $50 \%$. It is therefore appropriate to add $85 \%$ to survey counts made in the shallow waters of eastern Hudson Bay.

\section{ACKNOWLEDGEMENTS}

This work was supported by the Department of Fisheries and Oceans under the Federal Plan for the Development of Quebec Fisheries and under the Aboriginal Fisheries Strategy. We thank the communities of Kuujjuaraapik, Umiujaq, Inukjuak, and Salluit for their cooperation and support, and the local hunters, who lent us their knowledge of local conditions and beluga behaviour to help with transport, camping, and catching and tagging belugas. We thank the Makivik Corporation, particularly Dr. D.W. Doidge, for cooperation, support, and help in the field. We thank the guest editors and reviewers for the improvements they suggested.

\section{REFERENCES}

ANONYMOUS. 1993. Agreement between the Inuit of the Nunavut Settlement Area and Her Majesty in Right of Canada. Ottawa: Department of Indian Affairs and Northern Development and Tungavik Federation of Nunavut. 229 p.

BROWN GLADDEN, J.G., FERGUSON, M.M., and CLAYTON, J.W. 1997. Matriarchal genetic population structure of North American beluga whales Delphinapterus leucas (Cetacea: Monodontidae). Molecular Ecology 6:1033-1046.

CARON, L., and SMITH, T.G. 1990. Philopatry and site tenacity of belugas, Delphinapterus leucas, hunted by the Inuit at the Nastapoka estuary, eastern Hudson Bay. In: Smith, T.G., St. Aubin, D.J., and Geraci, J.R., eds. Advances in research on the beluga whale, Delphinapterus leucas. Canadian Bulletin of Fisheries and Aquatic Sciences 224. 69-79.

DFO (DEPARTMENT OF FISHERIES AND OCEANS). 1996. Northern Quebec belugas 5 year management plan: 1996-2000. Québec, Québec: Department of Fisheries and Oceans. 19 p. + Annexes.

FINLEY, K.J., MILLER, G.W., ALLARD, M., DAVIS, R.A., and EVANS, C.R. 1982. The belugas (Delphinapterus leucas) of northern Quebec: Distribution, abundance, stock identity, catch history and management. Canadian Technical Report on Fisheries and Aquatic Sciences 1123.57 p.

GASTON, A.J., CAIRNS, D.K., ELLIOT, R.D., and NOBLE, D.G. 1985. A natural history of Digges Sound. Canadian Wildlife Service Report Series 46. 63 p. 
GAUTHIER, I. 1999. Estimation de la visibilité aérienne des bélugas du Saint-Laurent et les conséquences pour l'évaluation des effectifs. Mémoire de maîtrise, Université du Québec à Rimouski, 300 ave des Ursulines, Rimouski, Québec, Canada. 104 p.

GERACI, J.R., and SMITH, G.J.D. 1990. Cutaneous response to implants, tags and marks in beluga whales Delphinapterus leucas and bottlenose dolphins Tursiops truncatus. In: Smith, T.G., St. Aubin, D.J., and Geraci, J.R., eds. Advances in research on the beluga whale, Delphinapterus leucas. Canadian Bulletin of Fisheries and Aquatic Sciences 224. 81-95.

HAIN, J.H.W., ELLIS, S.L., KENNEY, R.D., and SLAY, C.K. 1999. Sightability of right whales in coastal waters of the southeastern United States with implications for the aerial monitoring program. In: Garner, G.W., Amstrup, S.C., Laake, J.L., Manly, B.F.J., McDonald, L.L., and Robertson, D.G., eds. Marine mammal survey and assessment methods. Rotterdam: A.A. Balkema. 191-207.

HARWOOD, L.A., INNES, S., NORTON, P.A., and KINGSLEY, M.C.S. 1996. Distribution and abundance of beluga whales in the Mackenzie Estuary, southeast Beaufort Sea and west Amundsen Gulf during late July 1992. Canadian Journal of Fisheries and Aquatic Sciences 53:2262-2273.

HEIDE-JØRGENSEN, M.P., RICHARD, P.R., and ROSINGASVID, A. 1998. Dive patterns of belugas (Delphinapterus leucas) in waters near eastern Devon Island. Arctic 51(1):17-26.

KENDALL, M.G., and BABINGTON-SMITH, B. 1939. The problem of $m$ rankings. Annals of Mathematical Statistics 10: 275-287.

KINGSLEY, M.C.S. 1989. Population dynamics of the narwhal Monodon monoceros: An initial evaluation (Odontoceti: Monodontidae). Journal of Zoology (London) 219:201-208.

__ _ 2000. Numbers and distribution of beluga whales, Delphinapterus leucas, in James Bay, eastern Hudson Bay, and Ungava Bay in Canada during the summer of 1993. Fishery Bulletin 98:736-747.

KINGSLEY, M.C.S., and REEVES, R.R. 1998. Aerial surveys of cetaceans in the Gulf of St. Lawrence in 1995 and 1996. Canadian Journal of Zoology 76(8):1529-1550.

KINGSLEY, M.C.S., CLEATOR, H.J., and RAMSAY, M.A. 1994. Summer distribution and movements of narwhal in Eclipse Sound and adjacent waters, N.W.T. Meddelelser om Grønland, Bioscience 39:163-174.

LARSEN, F., HEIDE-JØRGENSEN, M.P., MARTIN, A.R., and BORN, E.W. 1994. Line-transect estimation of abundance of narwhals (Monodon monoceros) in Scoresby Sund and adjacent waters. Meddelelser om Grønland, Bioscience 39:87-92.
MARTIN, A.R., and SMITH, T.G. 1992. Deep diving in wild, freeranging beluga whales, Delphinapterus leucas. Canadian Journal of Fisheries and Aquatic Sciences 49(3):462-466.

MARTIN, A.R., KINGSLEY, M.C.S., and RAMSAY, M.A. 1994. Diving behaviour of narwhals (Monodon monoceros) on their summer grounds. Canadian Journal of Zoology 72:118-125.

NAMMCO (NORTH ATLANTIC MARINE MAMMAL COMMISSION). 2000. Report of the NAMMCO Scientific Committee Working Group on the population status of beluga and narwhal in the North Atlantic. In: Annual Report 1999. NAMMCO, Troms $\varnothing$, Norway. 153-188.

ORR, J.R., and HIATT-SAIF, M. 1992. A flipper band for individual identification of beluga whales (Delphinapterus leucas). Canadian Technical Report on Fisheries and Aquatic Sciences 1856. 9 p.

REEVES, R.R., and MITCHELL, E.D. 1987a. Catch history, former abundance, and distribution of white whales in Hudson Strait and Ungava Bay. Naturaliste canadien 114:1-65.

. 1987b. History of white whale (Delphinapterus leucas) exploitation in eastern Hudson Bay and James Bay. Canadian Special Publication on Fisheries and Aquatic Sciences 95. 45 p.

RICHARD, P.R., ORR, J.R., and BARBER, D.G. 1990. The distribution and abundance of belugas, Delphinapterus leucas, in eastern Canadian waters: A review and update. In: Smith, T.G., St. Aubin, D.J., and Geraci, J.R., eds. Advances in research on the beluga whale, Delphinapterus leucas. Canadian Bulletin of Fisheries and Aquatic Sciences 224. 23-28.

RICHARD, P.R., WEAVER, P.A., DUECK, L., and BARBER, D.G. 1994. Distribution and relative abundance of Canadian High Arctic narwhals (Monodon monoceros) in August 1984. Meddelelser om Grønland, Bioscience 39:41-50.

RICHARD, P.R., MARTIN, A.R., and ORR, J.R. 1997. Study of summer and fall movements and dive behaviour of Beaufort Sea belugas, using satellite telemetry: 1992-1995. Environmental Studies Research Funds Report 134. 26 p + Appendices.

SERGEANT, D.E. 1973. Biology of white whales (Delphinapterus leucas) in western Hudson Bay. Journal of the Fisheries Research Board of Canada 30:1065-1090.

. 1981. On permissible exploitation rates of Monodontidae. Report of the International Whaling Commission 31:583-588.

SMITH, T.G., and HAMMILL, M.O. 1986. Population estimates of the white whale, Delphinapterus leucas, in James Bay, eastern Hudson Bay and Ungava Bay. Canadian Journal of Fisheries and Aquatic Sciences 43:1982-1987.

SMITH, T.G., and MARTIN, A.R. 1994. Distribution and movements of belugas, Delphinapterus leucas, in the Canadian High Arctic. Canadian Journal of Fisheries and Aquatic Sciences 51:1653-1663. 